\title{
Purpose of Introduction as a Predictor of Invasiveness among Introduced Shrubs in Rwanda
}

\author{
Jean Leonard Seburanga \\ College of Science and Technology, University of Rwanda, Huye Campus, P.O. Box 117, Butare, Rwanda \\ Correspondence should be addressed to Jean Leonard Seburanga; seburanga@yahoo.fr
}

Received 19 June 2014; Revised 9 January 2015; Accepted 12 January 2015

Academic Editor: Curtis C. Daehler

Copyright ( 2015 Jean Leonard Seburanga. This is an open access article distributed under the Creative Commons Attribution License, which permits unrestricted use, distribution, and reproduction in any medium, provided the original work is properly cited.

\begin{abstract}
The introduced shrub flora in Rwanda was analyzed and the risk of invasion was assessed based on the species' purposes of introduction. The results showed that more than half of invasive alien shrubs in Rwanda were introduced as ornamentals. They include Agave americana L., Bryophyllum proliferum Bowie ex Hook., Caesalpinia decapetala (Roth) Alston, Lantana camara L., and Tithonia diversifolia (Hemsley) A. Gray. However, these represented only $3.16 \%$ of the total number of introduced ornamental shrubs. At the time when the study was conducted, no introduced food crop had become invasive. Species introduced for purposes other than food or culinary use showed higher likelihood of becoming invasive.
\end{abstract}

\section{Introduction}

There are approximately 300 invasive alien shrub species worldwide, including 30 species in African areas located beyond southern Africa [1]. In Rwanda, nine invasive alien shrubs have been identified (Seburanga et al., unpublished data). Despite the fact that the probability of an alien plant species becoming invasive is relatively low [2], invasive plants have become one of world's most serious threats to the conservation of biological diversity [3]. According to Sax [4], richness of invasive plant species correlates negatively with latitude and peaks towards the Equator, which puts Rwanda in the category of those countries that are prone to high levels of infestation. Unfortunately, data about introduced plants in Rwanda are lacking or outdated because they are often drawn from now outdated publications of the Belgian botanist Troupin, which are up to 30 years old [5]. REMA [6] indicated that new plant species were being introduced into Rwanda without any prior screening process. The introduced plants include invasive Jatropha for biofuel production.

In this paper, introduced shrub species are investigated and the risk of invasion was assessed based on their purposes of introduction. Mack [7] recognized that the prediction of which introduced species is likely to become invasive should also look into the role played by humans. Both global and local research have shown that many species that end up becoming invasive were first introduced for ornamental purpose [8-10]. The assessment of the likelihood of a plant becoming invasive based on its purpose of introduction may contribute to lowering the cost of the screening process and monitoring of new introductions, giving much attention to those species that are more likely to become invasive.

\section{Materials and Methods}

2.1. Study Area. The area covered by this study lies between $1^{\circ} 04^{\prime}$ and $2^{\circ} 51^{\prime}$ south latitudes and $28^{\circ} 45^{\prime}$ and $31^{\circ} 15^{\prime}$ east longitudes. The country has an average altitude of $1250 \mathrm{~m}$. The land is fundamentally hilly and the country is often referred to as the "land of thousand hills." The climate is tropical, with two rainy seasons, accounting for $78 \%$ of annual rainfall, and two dry seasons. The temperature is around $21^{\circ} \mathrm{C}$ in Kigali. However, it greatly varies with both altitude and land topography and can be as low as $1^{\circ} \mathrm{C}$ at Mount Karisimbi.

2.2. Data Collection and Analysis. Vegetation surveys were conducted to take records of alien shrub species that occur in the wild across Rwanda. Grid and meander transect sampling methods were used. In total, 26 grid cells from a $10 \times 10 \mathrm{~km}^{2}$ 


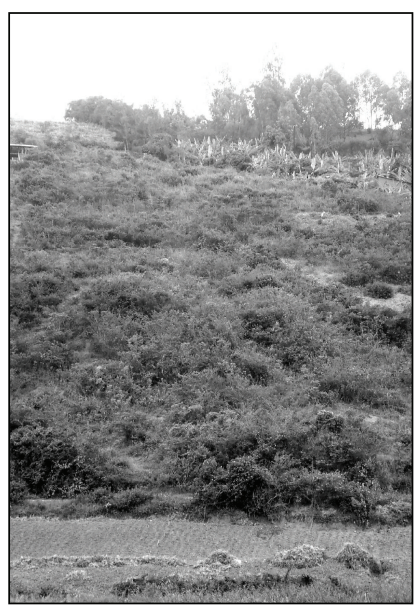

(a)



(b)

FIGURE 1: Lantana camara L.: a landscape transformer species within the agricultural matrix in Gahanga sector (Kigali) (a) and an ornamental garden plant in Nyakarambi, Kirehe District (b).

grid overlying Rwanda's elevation map were randomly chosen and surveyed using the meander method [11]. When present along the transect, the species was assigned the code "1." If absent, the value " 0 " was attributed. Information on the purpose of introduction of a species was drawn from an extensive review of the literature. Data were analyzed by simple screen plotting in Microsoft Excel and by a Chi-square test performed on invasive plant observed values and expected values. The expected values were computed assuming that the variable "species purpose of introduction" did not influence the species invasiveness; that is, the percentage of species that became invasive in each category of use out of the total number of invasive species considered in this study matches the proportions of species belonging in that category in the total introduced shrub flora, invasive and noninvasive species combined.

\section{Results}

A total of 178 alien shrub species were recorded, the bulk of which were introduced for ornamental purposes (Table 1). The proportion also varied by status: introduced versus invasive species. A Chi-square test result suggested that observed values in terms of percentage of invasive species by category of use differed greatly from expected proportions $\left(\chi^{2}=59.2, P<0.001\right)$. Only 5\% were introduced as food crops. More than half of invasive alien shrubs in Rwanda were introduced as ornamentals (Figure 1). They include Agave americana L., Bryophyllum proliferum Bowie ex Hook., Caesalpinia decapetala (Roth) Alston, Lantana camara L., and Tithonia diversifolia (Hemsley) A. Gray. However, these represented only $3.16 \%$ of the total number of introduced ornamental shrubs. Three species became invasive after they were introduced mainly for fencing and boundary marking (Mimosa pigra L., Opuntia ficus-indica (L.) Mill., and Opuntia monacantha Haw.). They accounted for $2 / 3$ of the total number of species introduced for that purpose. Species
TABLE 1: Main purpose of introduction of alien shrubs in Rwanda.

\begin{tabular}{lcccc}
\hline \multirow{2}{*}{ Species uses } & \multicolumn{2}{c}{ Introduced } & \multicolumn{2}{c}{ Invasive } \\
& $\begin{array}{c}\text { Species } \\
\text { count }\end{array}$ & $\%$ & $\begin{array}{c}\text { Species } \\
\text { count }\end{array}$ & $\%$ \\
\hline Ornamental crops & 156 & 87.64 & 5 & 55.56 \\
Food crops & 9 & 5.06 & 0 & 0 \\
Fencing and & 5 & 2.81 & 3 & 33.33 \\
boundary marking & 4 & 2.25 & 0 & 0 \\
Medicinal crops & 2 & 1.12 & 0 & 0 \\
Agroforestry crops & 1 & 0.56 & 1 & 11.11 \\
Fiber source & 1 & 0.56 & 0 & 0 \\
Biofuel & 178 & 100 & 9 & 100 \\
\hline Total & & & & \\
\hline
\end{tabular}

introduced for food or culinary use showed no ability to selfestablish in the wild. They included Cajanus cajan (L.) Huth, Rosmarinus officinalis L., Saccharum officinarum L., Solanum betaceum Cav., and Musa spp. No species of this category became invasive. Only Physalis peruviana L. and Capsicum frutescens L. successfully establish in the wild without becoming invasive. Agave sisalana Perrine was introduced for fiber extraction and was not invasive until its demand on the market plummeted both domestically and abroad. Ornamentals also topped the list of naturalized shrubs in the process of becoming invasive (5/7). They include Brugmansia suaveolens (Willd.) Bercht. \& Presl., Buddleja davidii Franch., Duranta erecta L., Lonicera japonica Thunb. ex Murray, and Solanum mauritianum Scop. The list does not include any food crop.

\section{Discussion}

The findings highlighting the predominance of ornamentals among the introduced shrubs in Rwanda (ornamental: food 
crop ratio $=17: 1$ ) are in accord with Khoshbakht and Hammer [12] who suggest that, in general, ornamental species outnumber food crops, invasive and noninvasive species combined (ratio $=4: 1$ ). However, it is not yet clear what causes the salient difference in terms of invasiveness between ornamentals and other categories of introduced species [13]. The suggestion of Prinzing et al. [14] that garden plants have traits that convey comparatively high potential to become invasive only partly explains the trend. It can be hypothesized that the differences in mode of exploitation and product lifecycle also have a role to play. Unlike ornamentals, the majority of food crops rely on human agency for preservation and propagation because a substantial amount of leaf biomass, fruits, and seeds they produce is destroyed through domestic consumption and industrial processing. Such a harvesting pressure prevents them from reproducing and establishing self-perpetuating populations at least as long as humans and other plant feeders have recourse on them. In evolutionary terms, the sustained pressure exerted on food crops results into strategic allocation of extra energy and nutrients in production of the resource of interest to humans. This leads to a loss of their potential for dispersal, establishment, and spread without human assistance [15]. In addition, much like fashion products, ornamentals have a short lifecycle and highly unpredictable demand curve [16]. As a result, they are spared from excessive exploitation because part of the oversupplies are left alone soon after the demand plummets and can reproduce and release propagules to the surrounding environment [17]. For instance, Lantana camara L. was introduced in Rwanda for its ornamental attributes (Figures 1(a) and 1(b)). When it escaped from cultivation, its demand on the market dropped significantly, which gave it chance to reproduce in the wild and spread without human disturbance. Similarly, the spread of Agave sisalana Perrine in recent times could be attributed to a significant decline in Agave fiber extraction that followed the advent of synthetic fibers. The finding that $C$. frutescens and P. peruviana, unlike other food crops, have shown ability to establish and maintain selfsustained populations in the wild despite fruit predation by birds and humans may be explained by the fact that, in most cases, seeds are not destroyed during predation. Instead the movement of predators spreads them away from the source plants through endozoochory. These few food crops whose seeds can pass through human gut without being crushed or their germination being inhibited [18] will still have difficulty dispersing naturally in modern times as their seeds land in latrines. Furthermore, indoor or gated gardening may further reduce the potential for long range dispersal should the plants be allowed to reproduce [19]. In such circumstances the majority of seeds are likely to be collected and buried into landfills. They may also be dispatched across agricultural fields if the managers elect to recycle the wastes into green manure. In that case, the reproductive cycle may still be disrupted through weed removal. Some crops have modified their genetics naturally and even evolved into new species, capable of striving in the wild. However, there are only a few of such cases. Ellstrand et al. [15] counted only thirteen cases worldwide, equivalent to roughly $0.2 \%$ of total domesticated crops.

\section{Conclusion}

The invasive alien shrub flora of Rwanda was analyzed species by species taking into account the purposes for which the species were introduced into Rwanda. Introductions for ornamental gardening and live fencing were most likely to become invasive. Food cropping did not promote species invasiveness. Unlike other food crops, fleshy-fruited Physalis peruviana L. and Capsicum frutescens L. appeared to benefit from dispersal through endozoochory and readily establish on their own. However, weed removal and the practice of burying wastes into latrines limit the species ability to maintain such self-established populations and spread to other areas.

\section{Conflict of Interests}

The author declares that there is no conflict of interests regarding the publication of this paper.

\section{References}

[1] D. M. Richardson and M. Rejmánek, "Trees and shrubs as invasive alien species-a global review," Diversity and Distributions, vol. 17, no. 5, pp. 788-809, 2011.

[2] S. V. Fowler, P. Syrett, and R. L. Hill, "Success and safety in the biological control of environmental weeds in New Zealand," Austral Ecology, vol. 25, no. 5, pp. 553-562, 2000.

[3] E. D. Yates, D. F. Levia Jr., and C. L. Williams, "Recruitment of three non-native invasive plants into a fragmented forest in southern Illinois," Forest Ecology and Management, vol. 190, no. 2-3, pp. 119-130, 2004.

[4] D. F. Sax, "Latitudinal gradients and geographic ranges of exotic species: implications for biogeography," Journal of Biogeography, vol. 28, no. 1, pp. 139-150, 2001.

[5] G. Troupin, Flore du Rwanda: Spermatophytes I-IV, Musée Royal de l'Afrique Centrale, Tervuren, Belgique, 1978-1988.

[6] REMA, Rwanda State of Environmental and Outlook: Our Environment for Economic Development, Rwanda Environment Management Authority, Kigali, Rwanda, 2009.

[7] R. N. Mack, "Predicting the identity of plant invaders: future contributions from horticulture," HortScience, vol. 40, no. 5, pp. 1168-1174, 2005.

[8] M. E. Nairn, P. G. Allen, A. R. Inglis, and C. Tanner, Australian Quarantine: A Shared Responsibility, Department of Primary Industries \& Energy, Canberra, Australia, 1996.

[9] P. E. Hulme, "Biological invasions in Europe: drivers, pressures, states, impacts and responses," in Biodiversity under Threat: Issues in Environmental Science and Technology, R. Hester and R. M. Harrison, Eds., pp. 55-79, Royal Society of Chemistry, Cambridge, UK, 2007.

[10] K. Dehnen-Schmutz and J. Touza, "Plant invasions and ornamental horticulture: pathway, propagule pressure and the legal framework," in Floriculture, Ornamental and Plant Biotechnology: Advances and Topical Issues, J. A. T. da Silva, Ed., pp. 15-21, Global Science Books, Gainesville, Fla, USA, 2008.

[11] C. D. Huebner, "Detection and monitoring of invasive exotic plants: a comparison of four sampling methods," Northeastern Naturalist, vol. 14, no. 2, pp. 183-206, 2007. 
[12] K. Khoshbakht and K. Hammer, "How many plant species are cultivated?" Genetic Resources and Crop Evolution, vol. 55, no. 7, pp. 925-928, 2008.

[13] L. C. Foxcroft, D. M. Richardson, and J. R. U. Wilson, "Ornamental plants as invasive aliens: problems and solutions in Kruger National Park, South Africa," Environmental Management, vol. 41, no. 1, pp. 32-51, 2008.

[14] A. Prinzing, W. Durka, S. Klotz, and R. Brandl, "Which species become aliens?” Evolutionary Ecology Research, vol. 4, no. 3, pp. 385-405, 2002.

[15] N. C. Ellstrand, S. M. Heredia, J. A. Leak-Garcia et al., "Crops gone wild: evolution of weeds and invasives from domesticated ancestors," Evolutionary Applications, vol. 3, no. 5-6, pp. 494504, 2010.

[16] D. Maaß, M. Spruit, and P. de Waal, "Improving short-term demand forecasting for short-lifecycle consumer products with data mining techniques," Decision Analytics, vol. 1, no. 4, pp. 117, 2014.

[17] D. Simberloff, "The role of propagule pressure in biological invasions," Annual Review of Ecology, Evolution, and Systematics, vol. 40, pp. 81-102, 2009.

[18] A. M. Bartuszevige and D. L. Gorchov, "Avian seed dispersal of an invasive shrub," Biological Invasions, vol. 8, no. 5, pp. 10131022, 2006.

[19] E. Weber and D. Gut, "Assessing the risk of potentially invasive plant species in central Europe," Journal for Nature Conservation, vol. 12, no. 3, pp. 171-179, 2004. 

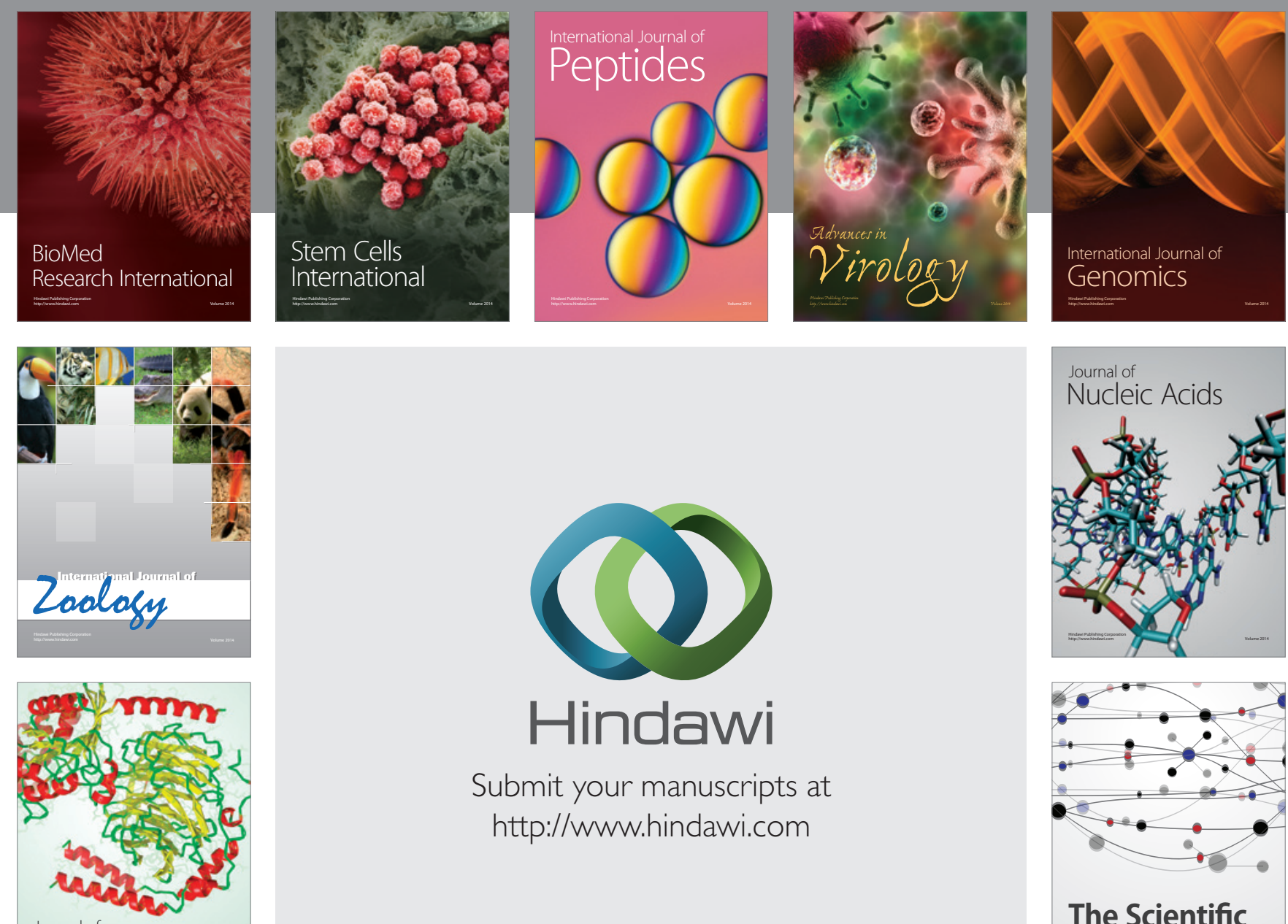

Submit your manuscripts at

http://www.hindawi.com

Journal of
Signal Transduction
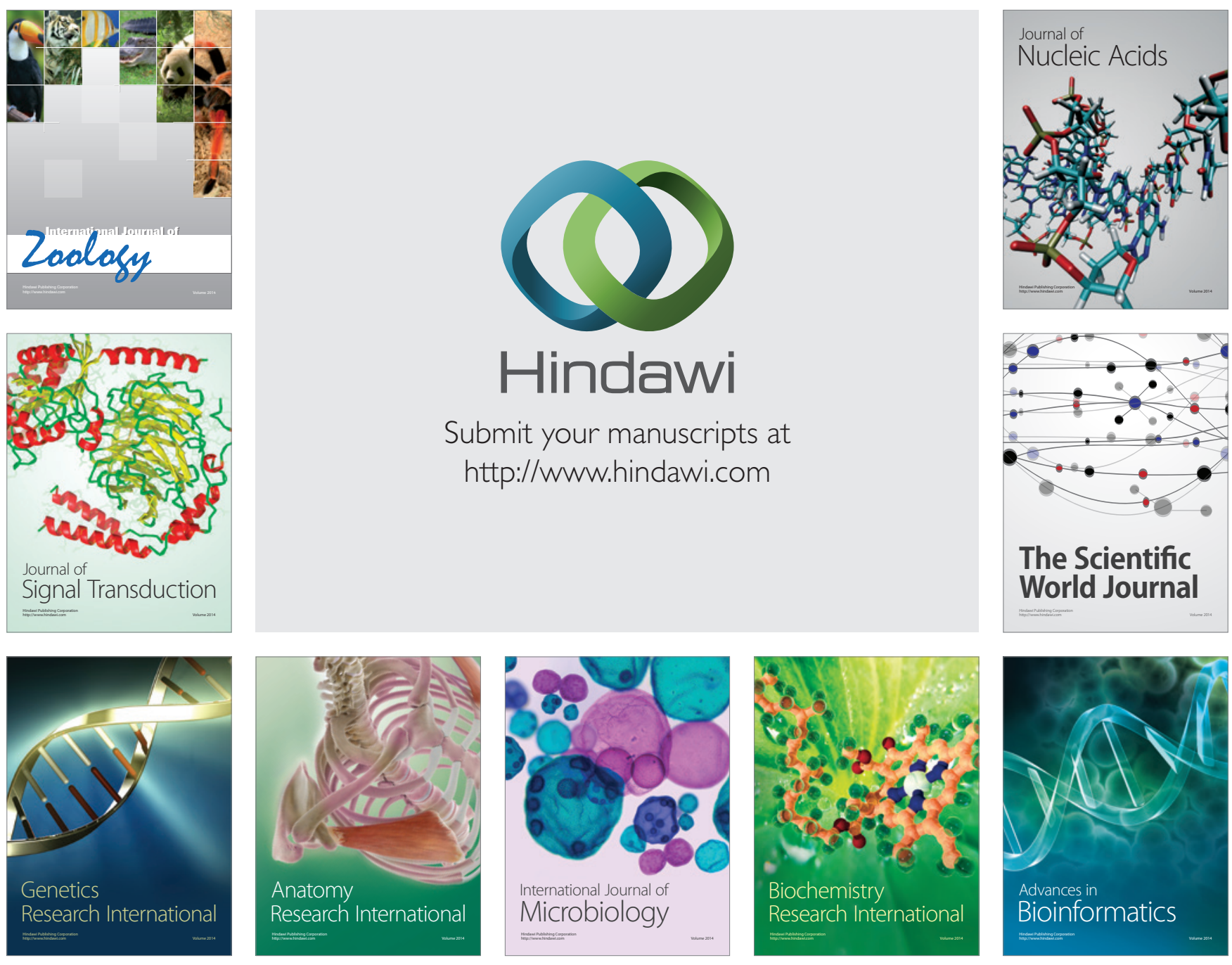

The Scientific World Journal
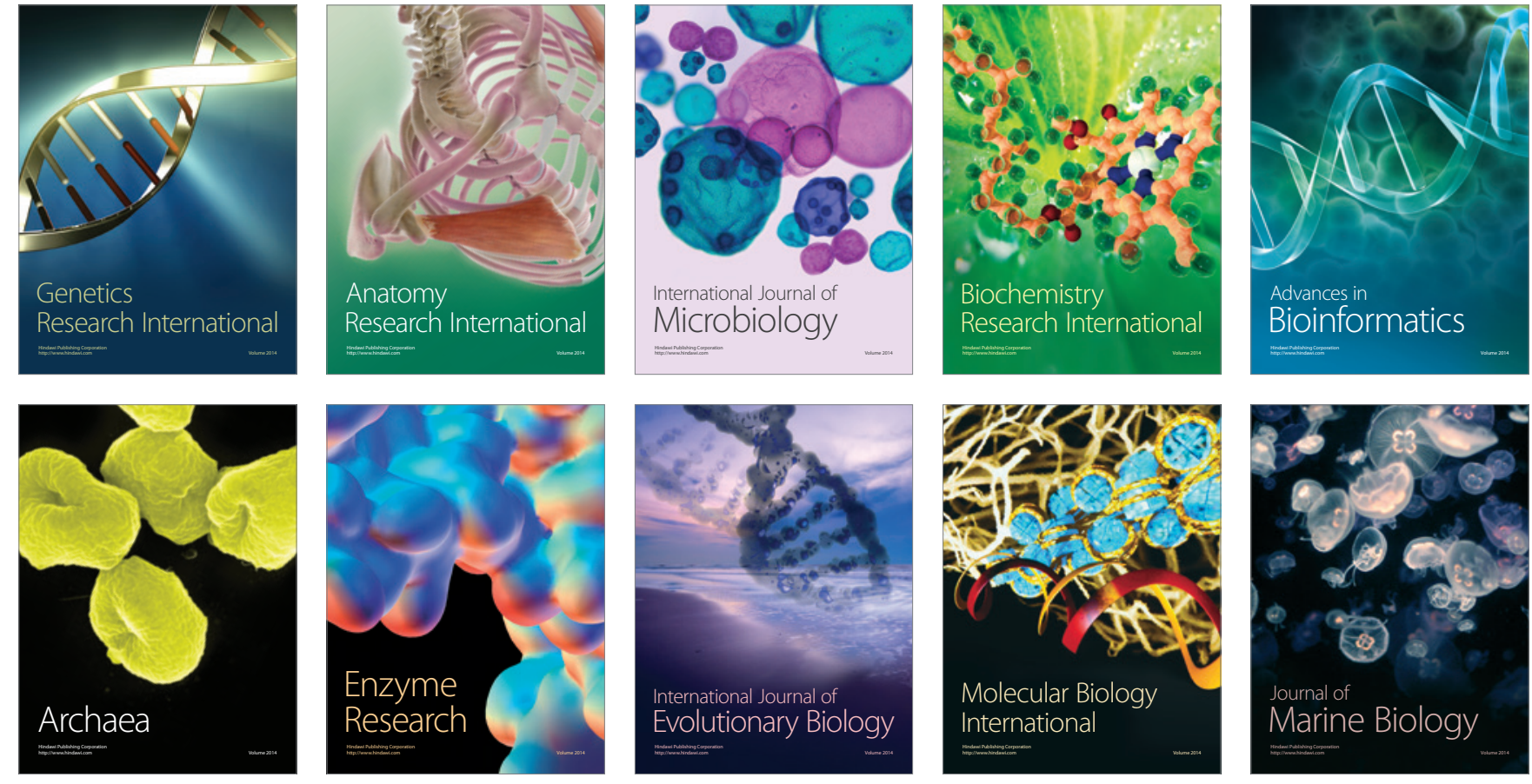